\title{
WHY IS IT IMPORTANT TO LEARN FINANCES? RESULTS BASED ON THE OPINION OF Z GENERATION*
}

\author{
Ágnes Csiszárik-Kocsir'1 \& Mónika Garai-Fodor ${ }^{2}$
}

UDC / UDK: 336.37-057.87

JEL classification / JEL klasifikacija: F65, I22

DOI: https://doi.org/10.22598/pi-be/2018.12.2.41

Preliminary communication / Prethodno priopćenje

Received / Primljeno: September 2, 2018 / 2. rujna 2018.

Accepted for publishing / Prihvaćeno za tisak: November 30, 2018 / 30. studenoga 2018.

\section{Summary}

The concepts of financial culture and financial literacy are today's popular research topic. Numerous research and analyses deal with topic of the financial culture of the population, and whether it has improved nearly ten years after the crisis. Different dimensions of financial culture are distinguished and examined for different age groups of the population. Nowadays, there are no countries that have not taken steps to develop and expand financial knowledge, but these steps have mostly been delayed. Many organizations deal with measuring the financial culture on the national and international level. The results of investigations have already in many cases drawn attention to deficiencies, and to the areas needing development, which is necessary and important.

Primary actors of development are educational institutions at the primary, secondary and tertiary level. But do students know the purpose of developing financial culture, do they recognize its importance? The aim of the study is to explore the views of students starting higher education on financial culture, financial literacy, the main motivations and goals in order to train future generations for future challenges and expectations in finances.

Key words: financial culture, financial literacy, Z generation, higher education.

\footnotetext{
The paper was presented at the 3rd International Conference „Business \& Entrepreneurial Economics BEE2018” which was held in Šibenik from 30 May to 2 June 2018 (www.bee-conference.com)

1 Ágnes Csiszárik-Kocsir, habil. Ph.D., Associate Professor, Óbuda University, Keleti Faculty of Business and Management, Budapest, Hungary, E-mail: kocsir.agnes@kgk.uni-obuda.hu

2 Mónika Garai-Fodor Ph.D., Assistant Professor, Óbuda University, Keleti Faculty of Business and Management, Budašest, Hungary, E-mail: fodor.monika@kgk.uni-obuda.hu
} 


\section{INTORDUCTION}

Increasing and developing financial literacy is in the interest of every national economy. Transition countries are particularly disadvantaged in international comparison, because they have entered the market economy without adequate knowledge. Members of the $\mathrm{BB}$ and $\mathrm{X}$ generations felt the absence of financial education and its necessity on their own skin. The global crisis in 2008 highlighted the importance of the issue. Nowadays younger generations ( $\mathrm{Y}$ and $\mathrm{Z}$ generations) have a significant advantage over previous generations. Financial education provides them with easier access to the financial world, but the question remains how much they can make use of the opportunities they already have. In this paper, we look for answers to this question.

\section{LITERATURE REVIEW}

Financial culture, financial literacy and financial consciousness are terms that are more and more often used and increasingly emphasized these days. The culture of humanity comprises several factors, including traditions, the past and certain economic - and consumer - elements too. The improvement of financial culture and knowledge is imperative for our future. Individuals who embrace the elements of financial culture, meaning that they are financially educated, will be able to improve the economic culture as entrepreneurs or managers, while on the other hand as consumers they will be able to make more conscious and wiser decisions in the future. The development of financial culture is not a new thing in the world. There had already been initiatives before the millennium regarding how to distribute and transmit financial knowledge on a broad scale. At that time those efforts were only concerned with passing on financial information, and mainly the Anglo-Saxon countries that had developed financial and bank systems were interested in them (Béres - Huzdik, 2012). The financial products introduced at that time have transformed so much in the years since that they cannot be understood with the knowledge of that era anymore. Therefore a solid basic financial knowledge is crucial, which can be developed and corrected, and a usable mass of information appropriate for this modern day and age can be built upon it.

Nearly ten years after the economic crisis the finances, the possession of money and the related knowledge have become more and more important, basically a part of our lives. The crisis and the subsequent events drew attention to the deficiencies connected to financial knowledge (Klapper - Lusardi - Panos, 2012). Due to the general prosperity and the unlimited liquidity prior to the crisis, certain age groups socialized in a way that they did not learn how to handle money, they did not learn how to make a budget, since the message that came from every direction said that the missing liquidity can be replaced with loans, several even. Before the crisis Johnson and Sherraden (2007) had already warned that it would be advisable to involve also the younger generation in the preparations of the financial processes by extending the taught subjects in a financial direction, or maybe by involving them in making the family financial decisions. Osana, Tucker and Bennett (2003) had the same opinion, because this way a larger financial responsibility can evolve. The loans taken out irresponsibly and the ear- 
ly, rash consumption can be connected - either directly or indirectly - with the absence of financial literacy and financial culture. The examination of the financial culture is a term or field of research with an ever growing popularity these days. Numerous articles, research, theses or dissertations deal with it, yet no specific, tangible steps have been made towards development. Every bigger bank treats the development of the financial culture as part of their corporate social responsibility (CSR), but they do not really have concrete results yet.

The term financial culture has not been given a uniform definition up until today. In the strict sense financial culture means financial literacy skills and capability, which requires special professional knowledge. According to the generally accepted definition it is "such a level of financial knowledge and skills, with the help of which the individuals are able to identify the basic financial information necessary for their conscious and cautious decisions, then after obtaining these information they are able to interpret them and on this basis they are able to make a decision, assessing its possible financial and other consequences for the future" (MNB - PSZÁF, 2008). Based on the definition of Atkinson and Messy (2012), financial culture is a sum of such skills, abilities, attitudes and patterns of behaviour that are essential for making the right financial decisions both on a personal and social scale. In the possession of financial literacy we can increase and improve prosperity, which can be felt not just at micro but at macro level as well. Based on the opinion of Luksander and her co-authors (2014), financial culture is nothing else but the ability of processing the financial information and making the right financial decisions. Suganya, Sakthivelrani and Durai (2013) outlined the substance of financial culture as the sum of such knowledge through which individuals are able to maximize their lifelong financial prosperity. Ultimately, it can be asserted that financial culture always means some sort of combination of abilities and skills, with which the personal and social well-being can be achieved. This is unimaginable without specific professional knowledge, so it can therefore be concluded that the role of financial education is unavoidable in this topic.

Knowledge that knows and understands the modern financial processes and is capable of adapting to changes is indispensable in today's globalized world. This is why Grifoni and Messy (2012) claim that the thrust of the term's meaning is a skill that is vital today. Financial culture can be split into parts, since it has levels that can be developed and others that are harder to develop. Those elements of the financial culture that can be modified easily and within a relatively short period of time with education and trainings belong to the former group. Such elements are for instance financial knowledge, financial skills and abilities. The parts of the financial culture that are difficult to develop are manifested in traditions, habits, specific seen and learnt norms, views and values (Balázsné, 2013). The latter, which is picked up from parents, family and friends, can be shaped the hardest, because due to the socialization it becomes a part of us, it is integrated into our character, hence it follows us all our lives (Koh - Lee, 2010). This process is called economic socialization, where the young generations learn from their educators the principles of using money and acquire the attitudes that will later broadly determine their success or failure in the financial world. The family has an emphasized role in this process, as they teach the principles of money management and usage that 
they find decisive (Zsótér, 2012). This is all connected to the previously introduced opinions, according to which we have to start developing financial consciousness already at school age in order to make the occasional negative habits somewhat correctible.

The assessment of financial culture in terms of a whole economy or society is not an easy task, but it can be declared that in the global financial world the evaluation of this field hints at the financial literacy of the individuals of an economy and society (Bárczi - Zéman, 2015). Certain research correlates financial culture with financial knowledge, while others refer to it as a financial attitude, financial proficiency or the possession of financial information. There is no common understanding about who is responsible for the development of this field either. According to certain opinions the development of financial literacy needs to be started during primary education, whereas others suggest that this should be the sole task of secondary schools. Financial culture or financial consciousness includes the adequate and applicable level of financial knowledge, or in other words the stock of material knowledge, in addition to concrete numeracy and math issues. OECD has been running comprehensive analyses on the financial culture of its member states for years, in which it assesses the financial knowledge, behaviour and attitude of the countries' nationals (OECD, 2016). In its latest survey it rewarded the financial culture of the countries with a maximum of 21 points, 7 of which for financial knowledge, 9 for financial behaviour and the remaining 5 for attitude. With regard to the examined OECD countries it can be stated that France had the best rating with 14.9 points. Poland ended up being last on the list with 11.6 points, which remains well below the average 13.7 points. Unfortunately, Hungary's result (12.4 points) is also below the average. However, it does not stand out from the average rating of the region (the Czech Republic had 12.6 points).

Developing the financial culture of students currently starting higher education is extremely important. They already belong to generation Z, who live the majority of their lives virtually, basing it on the Internet. Traditional education and administration is a burden to them, as they prefer electronic channels to the printed information sources. These youths are the main target groups of the increasingly digital bank system and the FinTech innovations. As we can see in our everyday lives, there is a paradigm shift in the financial sector (Kerényi - Molnár, 2017). As a consequence of the constant advance in globalization, the promotion of the role of the internet and the mobile communication becoming general, due to a lack of time the young generation is not willing to stand in queues at the bank anymore to deal with a simple administrative issue. They think in applications and they would like to handle their affairs electronically, and therefore they also want to deal with their banking transactions electronically (through their mobile phone) (Menon, 2016), since the youths of generation $\mathrm{Z}$ were already "born with mobile phones in their hands". Harmful effects of the process has already taken its toll on traditional human communication, and they will be noticeable with respect to the bank communications as well. This can only be avoided if we provide the necessary basic financial knowledge, since an application will not explain the characteristics of financial products. The 2016 research conducted by the FED faithfully reflects the above on the basis of the age distribution of people using mobile banking, which is illustrated in the below graph. As shown, youths between 18 and 29 years of age are miles ahead in mobile banking, which confirms the above features. 
Figure 1: Mobile banking rates (\%) among respondents

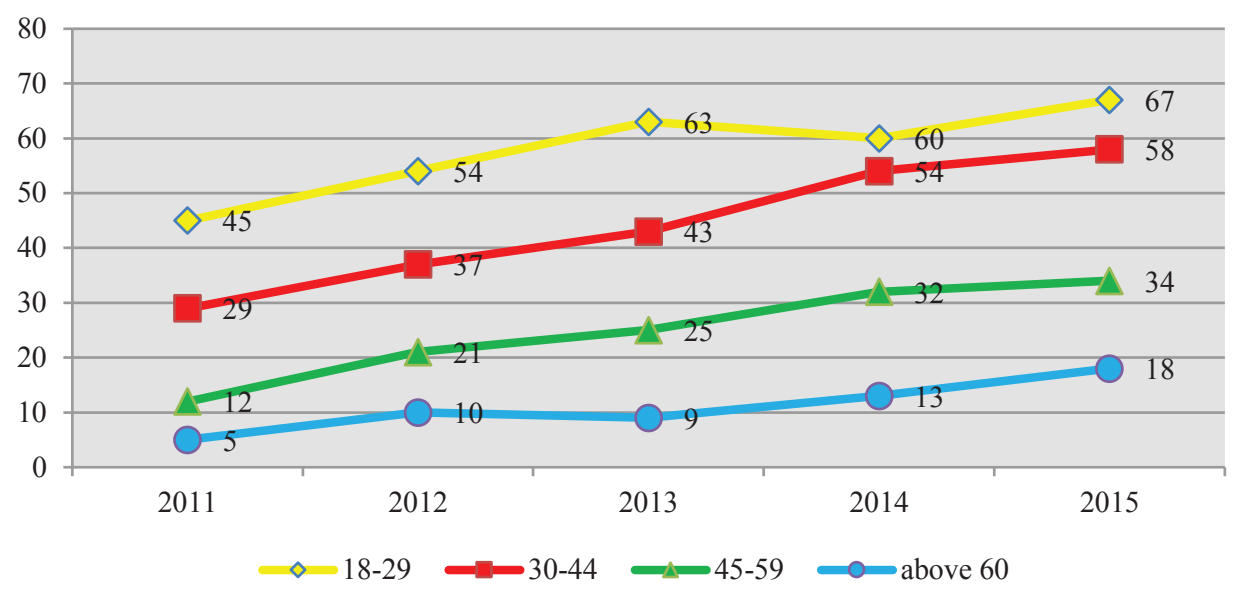

Soruce: own compilation according to FED, 2016

Understanding the ever-developing banking industry is not easy, and education cannot keep pace with numerous innovations and developments either, although it is probably not even part of its tasks. The most important mission of the education system would be giving a solid basic financial knowledge to the students, so they would not have to step out into the real financial world without "ammunition".

In accordance with today's requirements, the development of financial culture and knowledge is the task of not just the education system but of financial institutions too, and they often deal with this field as part of their CSR activities (Lentner et.al, 2015). Development of financial culture - as a key word - always has a positive message, and there are also positive examples and initiatives on this subject (competitions organized by banks for primary and secondary school students, information brochures, courses, etc.). The point is that the development of the financial culture of the young generation is critical, which cannot be done without conducting some sort of preliminary assessment concerning their basic knowledge. After the level assessment it would be necessary to develop a strategy involving all stakeholders (banks, education, government), so that the last foothold of the education system could breed prepared economic operators who are not financially illiterate.

\section{MATERIAL AND METHODS}

The basis of the study was a questionnaire survey conducted in the autumn of $2017^{3}$. Research was done with the help of a pretested standardized questionnaire form.

\footnotetext{
${ }^{3}$ I hereby would like to thank the students who contributed by filling the questionnaire form for all their help.
} 
The questionnaire did not contain open questions for statistical assessment purposes. The finalization of the questionnaire was preceded by four earlier rounds: a primary quantitative research conducted in 2015, qualitative surveys from 2015 and 2016, and a questionnaire survey carried out in the spring of 2016, as a result of which I was able to come to conclusions from a sample of 3736 people in the form of numerous studies. The current format of the questionnaire was based on the results of former research, and it examined a number of issues, from the value of money through the correct usage of financial and investment information to ethical questions, tailored especially to students entering into higher education for the reason of evaluating their financial knowledge. The questionnaire was filled by students of several higher education institutions, who began their studies in the autumn of 2017 within undergraduate education or higher-education vocational training. The questionnaire was filled by 942 respondents in total, but unfortunately only 768 could be assessed.

Figure 2: Composition of the sample based on residence and housing conditions

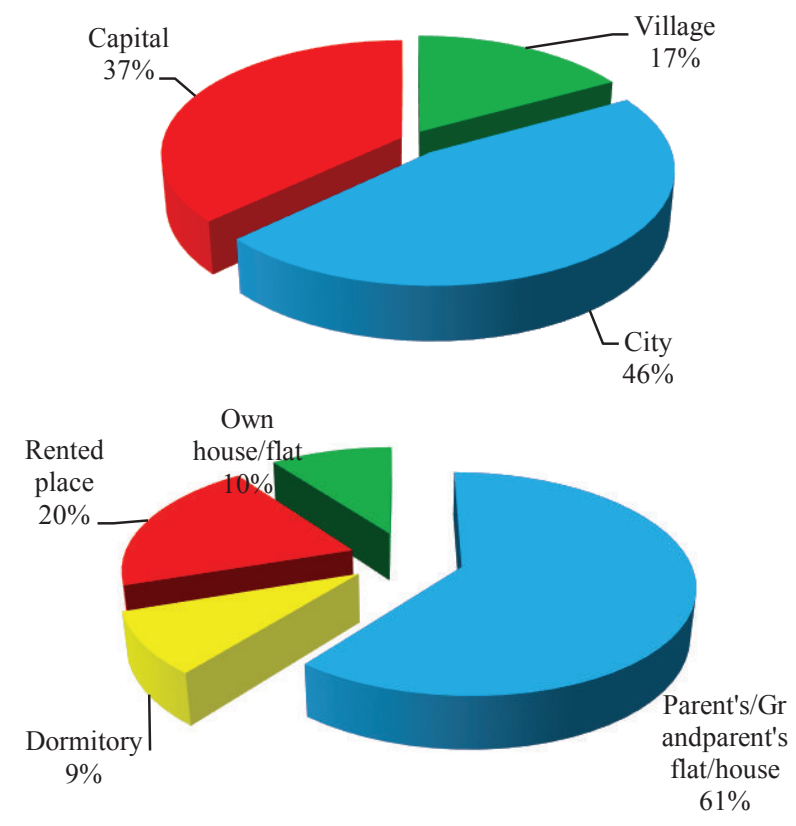

Source: own research, $2017, \mathrm{~N}=768$

The questionnaire consisted of 16 questions, 9 of which serving the segmentation of the respondents. The questions covered many fields, from the value of money through financial consciousness to the assessment of basic knowledge. The questionnaire was accessible online, ensuring the anonymity of the respondents. For the segmentation of the respondents I asked about their age, gender, residence-related information, income 
and education level of the parents, among other things, including if the respondents had studied finance before or not. Among the questions there were multiple choice questions and rating scales too. The questionnaire was filled by students of the Eszterhazy Karoly University, Pannon University, Szent Istvan University and Óbuda University, regardless of the faculties. The only condition of the participation was for the students to start their academic studies at the time of filling the questionnaire, so the ones attending master's degree programmes were not included in the sample. The sample was not considered to be representative, but it provided for the possibility of later establishing representative research. The results of the questionnaire presented in this study were obtained with the help of the SPSS 19.0 and MS Excel 2010 programs. The results of the present study were evaluated primarily by the student's residence, i.e. whether the student is living in a separate apartment or his parents'. We intend to analyse the subject in the course of other studies as well on the basis of the education level of the parents, income, employment and previous financial preparatory studies.

\section{RESULTS}

A lot of people have already analysed and highlighted - directly or indirectly the significance of financial education, as the above literature review showed. In this study we can learn the opinion of the young generation starting their higher education, as they are still able to assess the practical benefits of financial education almost without being influenced by others. 10 factors were listed in the questionnaire form from the aspects of practical utility, from the social objectives to personal benefits. The statements and the rate of the affirmative answers are illustrated in the table below.

Table 1: The practical benefits of learning finances based on respondents' opinion

\begin{tabular}{|l|c|}
\hline & Ratio \\
\hline Because with the possession of financial knowledge I can seize my financial opportunities better. & $85,94 \%$ \\
\hline Because I can make more conscious financial decisions if I possess relevant information. & $83,59 \%$ \\
\hline Because this way I can avoid making irresponsible financial decisions (indebtedness, losses, etc.) & $73,96 \%$ \\
\hline Because this way the banks and financial institutions have a lesser chance to mislead me. & $70,83 \%$ \\
\hline Because I can help my family too in making financial decisions. & $64,06 \%$ \\
\hline Because I will become more confident in the financial spheres. & $60,68 \%$ \\
\hline Because this way I can increase my assets. & $50,52 \%$ \\
\hline Because I can understand the financial products and constructions better. & $41,67 \%$ \\
\hline Because I can choose between the financial products more efficiently. & $39,58 \%$ \\
\hline Because I can achieve a higher yield on my savings. & $38,28 \%$ \\
\hline
\end{tabular}

Source: own research, 2017, N = 768 
As it is shown in the table, being able to increase their opportunities through studying finance is the most important factor to the responding students. In their opinion the other most important usefulness of financial studies is building up their financial consciousness, which helps them make more stable and careful decisions with regard to any kind of financial investments or products. On top of these they also find it valuable that if they are aware of the happenings in the financial world and the details of the financial products, then the irresponsible and unfounded financial decisions become avoidable. The students claimed, with a rate of $70 \%$, that if they have confidence in the field of finance then they could not be misled by the banks that easily, as the banks will not be able to make them accept any kind of product with any kind of explanation. Interestingly, they do not deem financial education relevant or important (below 40\%) in connection with financial success. In other words, they do not believe that in the possession of financial knowledge they will be able to choose more effectively between financial products, nor do they think that knowledge entitles them to achieve a higher yield. Another interesting fact is that the social dimension of the listed characteristics appears strongly based on the replies of the respondents, as $64 \%$ of them said that financial background knowledge is paramount also because through that knowledge they will be able to help their families or acquaintances, the ones that are clueless regarding financial decisions.

Hereinafter we introduce the above statements on the basis of the respondents' residence and housing conditions. From the perspective of the students it is vital where they live, since it affects their everyday lives and opportunities greatly. Those students who live in the capital or in a town have a lot more options. They can get jobs, pick and choose from a wider range of financial institutions, there are a wider variety of financial options becoming available to them. On the other hand, the ones who live in a village can only access these opportunities in towns, so from this aspect their conditions are limited. This has an impact on the quality of their everyday life, and what is more, it even influences the level of available primary and secondary education too. The options of the students living in a village are more modest, which can shape their way of thinking in terms of financial literacy.

From the sample segmented by place of residence, first we would like to present the opinion of students living in the capital. 284 of the 768 students lived in Budapest, which represents $37 \%$ of the sample. It can be established that teaching finance is also important for the students living in the capital, since that way they can make use of their opportunities better. Additionally, they will be able to make more conscious financial decisions as well, and at the same time studying finance reduces the risks of being misled by banks too. In terms of the above, living in the capital provides more options for the students. The answers reflect that as well, given that the assessment of the first statement was 1.4 percentage points higher in the case of students in this segment. It can also be seen from the detailed analysis of the students living in the capital that although they are ranked higher with regard to helping their family in making financial decisions, the rate of their answers diverges from the sample average by 4.2 percentage points. These students put better understanding of financial products, the achievement of a higher yield and choosing more efficiently between the products to the bottom of the list, but 
none of these statements are at the last place with respect to the sample mean. We can also acknowledge that in the case of students living in the capital the focus is rather on self-interest when it comes to ranking the advantages, while the indirect benefits are ranked lower, as the below graph shows.

Figure 3: The practical benefits of learning finances based on respondents' opinion living in the capital

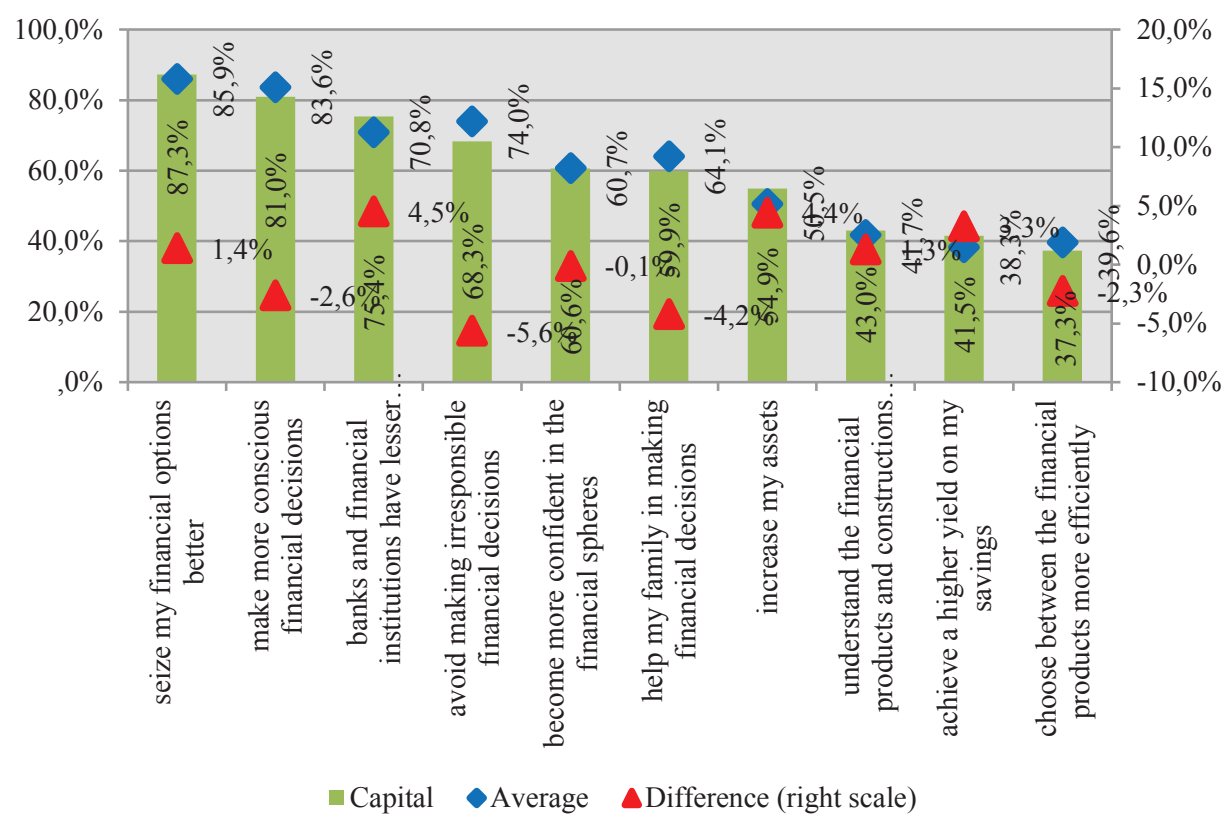

Source: own research, 2017, N = 768

Of the students who constituted the sample 354 lived in a town, which represents nearly half of the whole sample (46\%). Towns can offer numerous opportunities too for the students, yet there are fewer choices, supply, jobs and financial providers than in the capital. With regard to students living in a town the priorities are reversed. They rather ranked the possibility of conscious financial decisions first, giving it a rating 1.2 percentage points higher than the sample mean. This was followed by the benefit of seizing the opportunities, which becomes available via studying financing. The rate here was somewhat lower - by 2.3 percentage points - than the average of the whole sample. What is also peculiar is that the students living in a town believed that by studying finance the irresponsible financial decisions would be avoidable. This is a huge leap, because based on the opinion of the whole sample this statement only took the third place from the bottom. Helping others to make financial decisions got a relatively higher priority as well, which indicates the social dimension, sensitivity towards others. The 
three lowest ranked statements were the more efficient choices between products, better understanding of financial products and reaching a higher yield. Consequently, self-interest was rather marginalized in the case of students living in a town, as the graph below illustrates.

Figure 4: The practical benefits of learning finances based on respondents' opinion living in cities

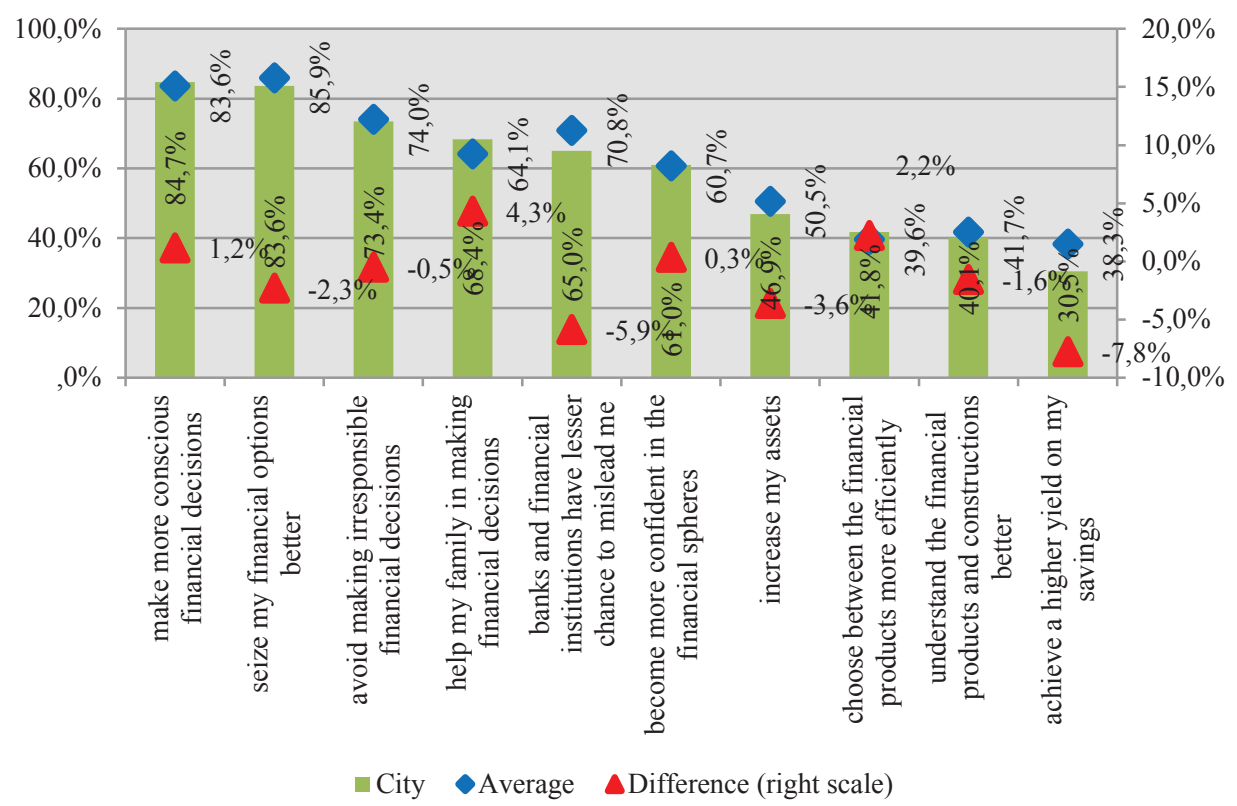

Source: own research, $2017, \mathrm{~N}=768$

Within the sample the number of students living in a village was 130, thus this segment was the lowest, representing only $17 \%$ of the entire sample. When analysing the opinion of the students living in a village, it can be seen that seizing the opportunities and the avoidance of making irresponsible decisions were in the first place. They thought that through possessing financial knowledge, more conscious decisions could be made, and it would be less likely for them to be misled by banks. Helping in making financial decisions took priority again here. It can also be asserted that in their opinion the first five factors were rather based on knowledge and helping others. Interestingly, a smaller emphasis was put by them on enrichment, reaching a higher yield, better understanding of financial products and choosing more efficiently between products. Presumably it is partially because there are smaller opportunities for students living in a village than in the case of the first two segments, they do not have such a room for manoeuvre, and most likely this is the situation with their family members too. Therefore they would prefer to spend energy on increasing their own knowledge instead, with 
which later they will be able to draw benefits for themselves in any event. The results are illustrated in the graph.

Figure 5: The practical benefits of learning finances based on respondents' opinion living in villages

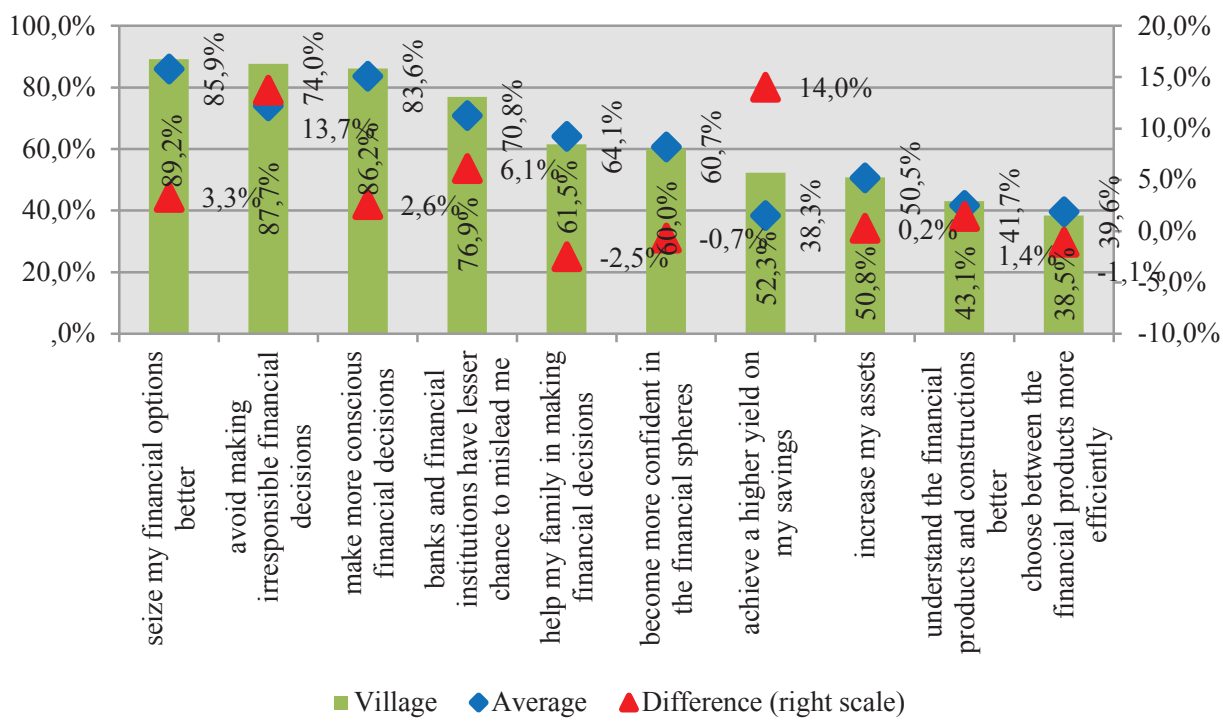

Source: own research, $2017, \mathrm{~N}=768$

Hereinafter we will examine the results based on the responding students' housing conditions. First, let us take a look at the students living with their parents or grandparents. There were 466 of them, constituting $61 \%$ of the sample. Residing with parents means some sort of convenience for the students, since they are supported by their parents or grandparents to some extent. Supposedly they will not make the students pay overhead costs and they will provide food to them, which will all be cost savings, compared to the students who are completely self-sustaining. The students residing with parents or grandparents are a bit more comfortable, so no wonder this sort of lifestyle is called "Hotel Mama" in common slang. Seizing the opportunities, making conscious financial decisions and understanding the financial products better took precedence in the case of these students as well when ranking the advantages. These were followed by reaching a higher yield and reducing the possibility of being misled by banks. With regard to the first three factors, the students definitely wished to absorb opportunities and knowledge through financial education. Self-interest came next, such as for example earning higher returns, since these students potentially have the option of saving their income that they can place in financial institutions to yield interests, for which knowledge is needed. On their list the last three factors were avoiding irresponsible financial 
decisions, increasing the assets and helping their family in making financial decisions. In other words the broader social usefulness of financial knowledge ended up being least important to the students living with parents or grandparents, just like in terms of the whole sample.

Figure 6: The practical benefits of learning finances based on respondents' opinion living with their parents/grandparents

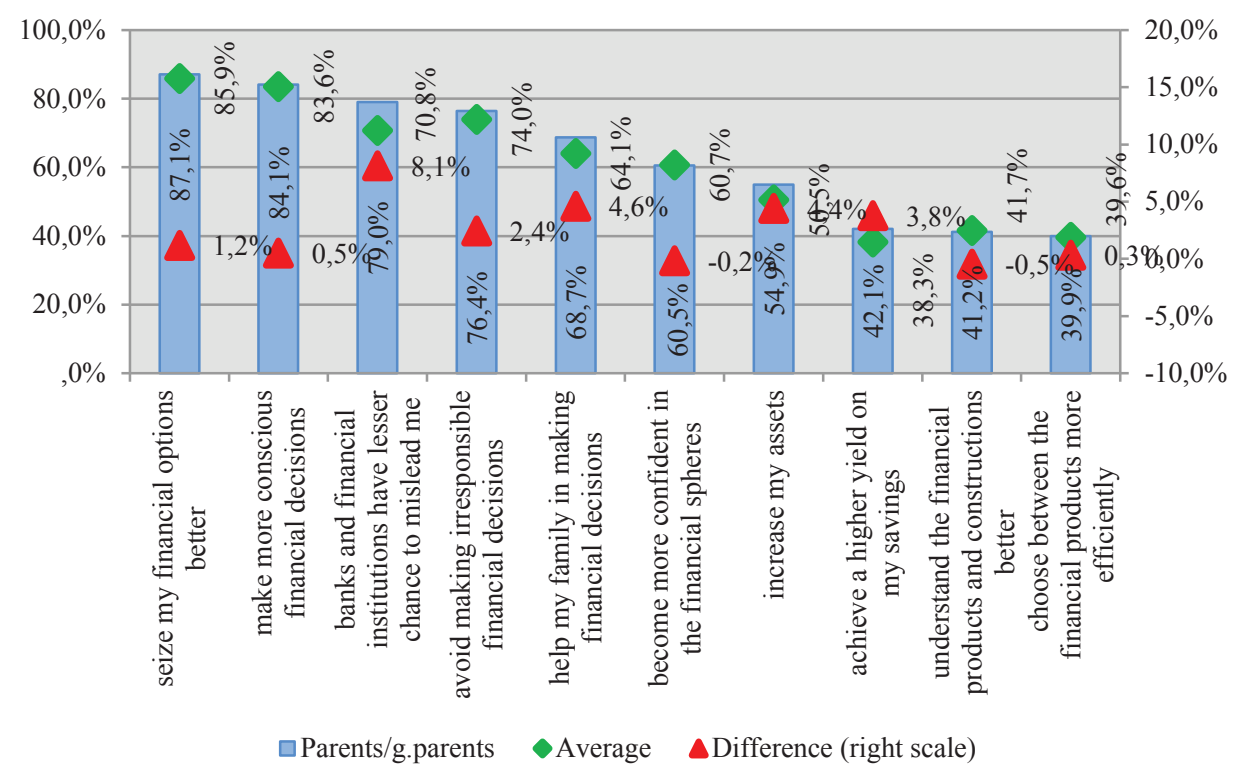

Source: own research, $2017, \mathrm{~N}=768$

Of the students filling the questionnaire, only 70 lived in a dormitory, which is not even $10 \%$ of all the responding students. In relation to students living in a dormitory it can be stated that making more conscious financial decisions was the most important to them, which represents a higher rate than the sample mean by 7.8 percentage points. They ranked the exploitation of opportunities lower, which is also shown by the $8.8 \%$ difference to the data of the whole sample. They also found the reduction of the possibility of being misled by banks significant, along with the avoidance of making unfounded financial decisions, the solutions of which they also saw in studying finance. The bottom three statements were reaching higher returns, the more effective choices and better understanding of financial products, as the graph illustrates. 
Figure 7: The practical benefits of learning finances based on respondents' opinion living in the dormitory

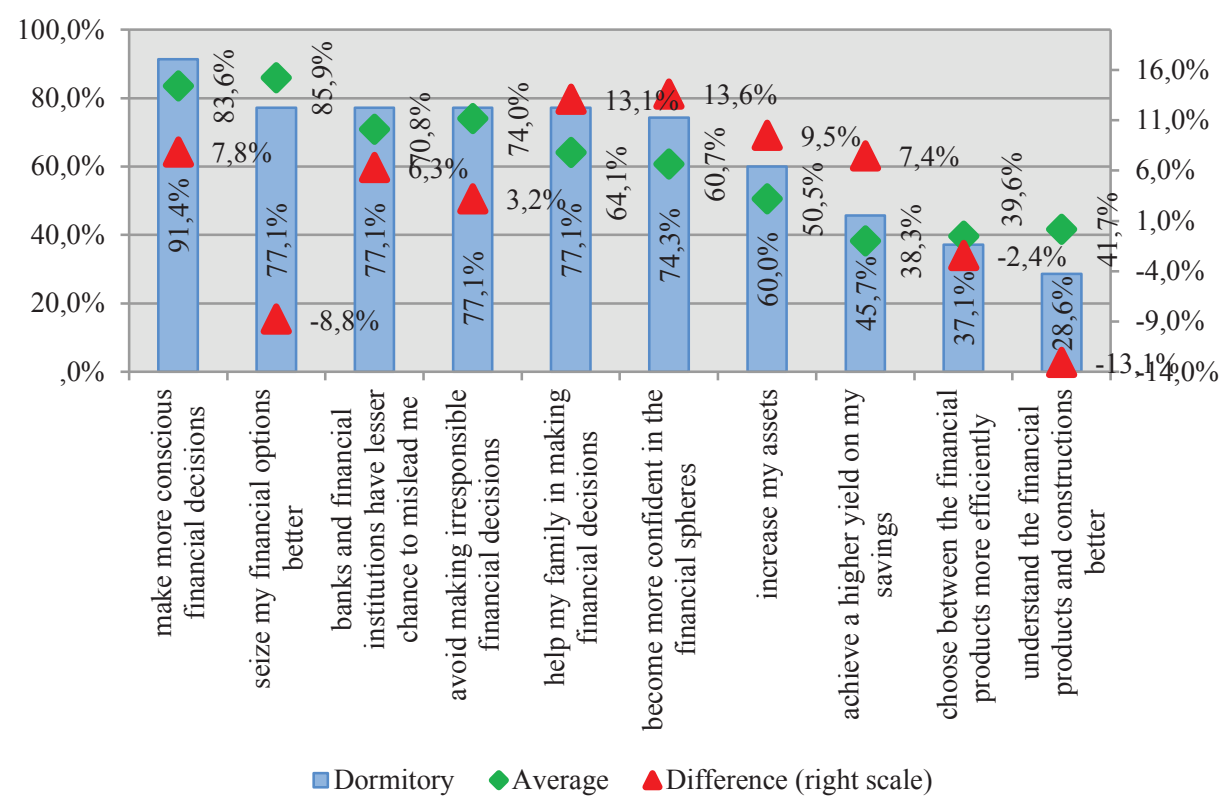

Source: own research, $2017, \mathrm{~N}=768$

154 of the students in the sample were accommodated in rented places. Considering the property prices these days, renting rooms or flats is not cheap at all, not even when the rent is shared between several students. Covering or earning the rent is not a small burden for the students or the parents and grandparents who are helping them, therefore the students living in rented flats also prioritized taking advantage of the opportunities, making conscious financial decisions and the avoidance of making irresponsible ones. The factors at the end of the list more or less mirrored the opinion of students in dorms, because they have to carry out their studies under the same conditions, through self-sufficiency. 
Figure 8: The practical benefits of learning finances based on respondents' opinion living in rented flat/house

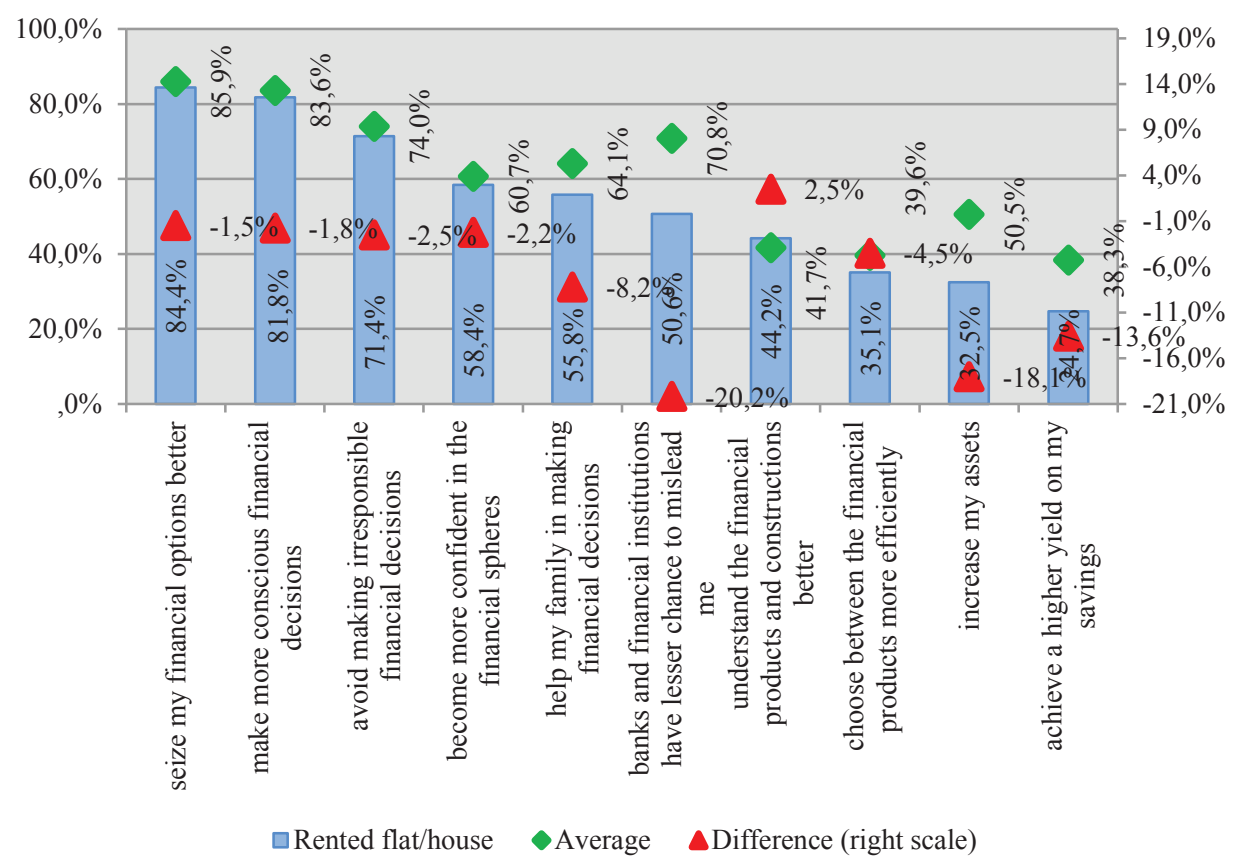

Source: own research, $2017, \mathrm{~N}=768$

Only a small number of students indicated during the questionnaire survey that they lived in their own home. This meant 78 students in total, constituting $10 \%$ of the entire sample. The students living in their own home are forced to be completely self-sufficient, which obviously does not exclude help from the parents and grandparents either. They also put seizing the opportunities and making conscious decisions first, and they see the solution to preventing irresponsible financial decisions and to reducing the possibility of being misinformed by banks in financial education as well. It is significant from their point of view that they don't consider helping others in making financial decisions to be a relevant goal, and they rather prioritize their own well-being and interests, as it is shown in the graph too. 
Figure 9: The practical benefits of learning finances based on respondents' opinion living in their own flat/house

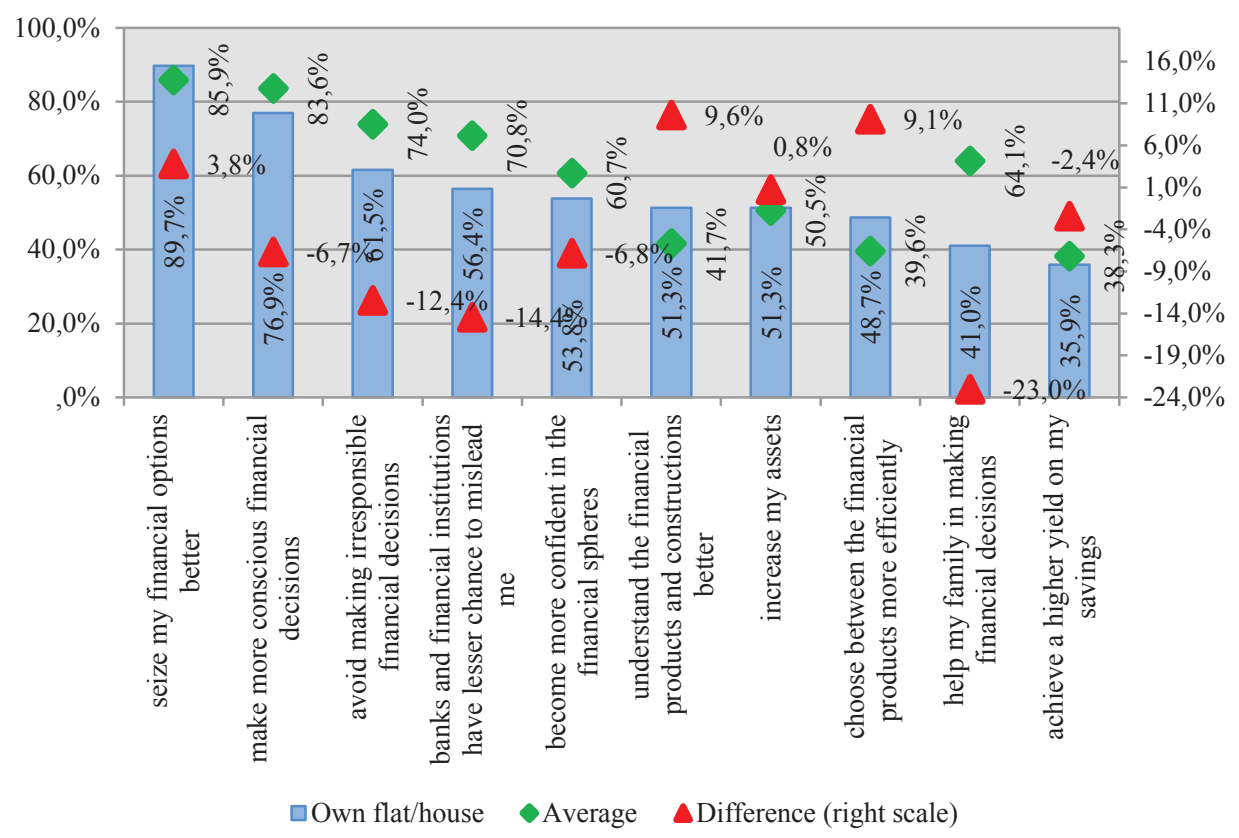

Source: own research, 2017, N = 768

\section{CONCLUSION}

In view of the above analysis it can be established that the students comprising the sample considered as a whole that studying finance was the key to their own prosperity. The majority of them saw the opportunity in receiving the necessary knowledge, which will help them with assessing and understanding their options through the acquisition of consciousness and experience. Instead of being financially illiterate, via their financial education the students will be able to become customers of banking products as conscious consumers, and they will not have to rely on the limited amount of information the bank assistants provide while evidently highlighting the beneficiary characteristics of the banking products.

By possessing this knowledge, they will not be vulnerable to the banks, and they will be able to grow their assets more too. What is problematic is that the students didn't deem the dissemination of financial knowledge substantial, although with its help there would also be an opportunity to promote the financial culture on a wider scale. The results showed that the students found the dissemination and definition of financial culture important. The most urgent challenge of the near future would be to find the method through which we could make our knowledge even more solid and practical in 
order for the growth of financial consciousness to become felt in the economy both at home and abroad as soon as possible.

\section{REFERENCES:}

1. Atkinson, A. - Messy, F.A. (2012): Measuring Financial Literacy, OECD Working Papers on Finance, Insurance and Private Pensions No. 15, http://www.oecd-ilibrary.org/docserver/download/5k9csfs90fr4-en.pdf?expires=1498684984\&id=id\& accname $=$ guest $\&$ checksum $=$ C5B34DF2381775999E9EFC9A4A5B956D, letöltve: 2016.08.04.

2. Balázsné Lendvai, M. (2013): A bankmarketing szerepe a pénzügyi kultúra fejlesztésében, Doktori Ph.D. értekezés, Nyugat-Magyarországi Egyetem, Sopron, http://ilex.efe. hu/PhD/ktk/balazsnelendvai/disszertacio.pdf, letöltve: 2016.10.05., (Hungarian)

3. Bárczi J. - Zéman Z. (2015): A pénzügyi kultúra és annak anomáliái, Polgári szemle, vol. 11, no. 1.-3., 101. - 108. pp. (Hungarian)

4. Béres, D. - Huzdik, K. (2012): A pénzügyi kultúra megjelenése makrogazdasági szinten, Pénzügyi Szemle, vol. 57, no. 3., 322.-336. pp. (Hungarian)

5. Federal Reserve /FED/ (2016): Consumers and Mobile Financial Services 2016, https://www.federalreserve.gov/econresdata/consumers-and-mobile-financial-services-report-201603.pdf, letöltve: 2018.01.02.

6. Grifoni, A. - Messy, F.A. (2012): Current Status of national Strategies for Financial Education; a comparative analysis and relevant practices, OECD Working Papers on Finance, Insurance and Private Pensions, No. 16.

7. Johnson, E. - Sherraden, M.S. (2007) From financial literacy to financial capability amog youth, Journal of Sociology and Social Welfare, vol. 34, no.3., 119.-145. pp.

8. Kerényi, Á. - Molnár, J. (2017): A FinTech-jelenség hatása - Radikális változás zajlik a pénzügyi szektorban?, Hitelintézeti Szemle, vol. 16, no. 3., 32-50. pp. (Hungarian)

9. Klapper, L. - Lusardi, A. - Panos, G.A. (2012): Financial Literacy and the Financial Crisis. Policy Research Working Paper. Washington, The World Bank.

10. Koh, N.K. - Lee, C.B. (2010): "Because My Parents Say So"- Children's monetary decision making, Procedia Social and Behavioral Sciences, vol 9., 48.-52. pp.

11. Lentner, Cs. - Szegedi, K. - Tatay, T. (2015): Társadalmi felelősségvállalás a bankszektorban, Pénzügyi Szemle, vol. 60, no. 1., 96.-104. pp. (Hungarian)

12. Luksander, A. - Béres, D. - Huzdik, K. - Németh, E. (2014): A felsőoktatásban tanuló fiatalok pénzügyi kultúráját befolyásoló tényezők vizsgálata, Pénzügyi Szemle, vol. 59, no. 2., 237. - 258. pp. (Hungarian)

13. Magyar Nemzeti Bank - Pénzügyi Szervezetek Állami Felügyelete (2008): Együttmüködési megállapodás a pénzügyi kultúra fejlesztés területén, https://www.mnb. 
hu/letoltes/0415mnbpszafmegallpodas-penzugyi-kultura-fejleszte.pdf, letöltve: 2012.04.12. (Hungarian)

14. Menon, Ravi (2016): Singapore's FinTech journey - where we are, what is next, FinTech Conference, Singapore, 16 November 2016., http://www.bis.org/review/ r161118a.htm. Letöltés ideje: 2017.11.24.

15. OECD (2016): OECD/INFE International Survey of Adult Financial Literacy Competencies

16. Osana, H.P. - Tucker, B.J. - Bennett, T. (2003): Exploring adolescent decision making about equity: Ill-structured problem solving in social studies. Contemporary Educational Psychology, vol. 28, 357.-383. pp.

17. Suganya, S. - Sakthivelrani, S. - Durai, K. (2013): Development and validation of financial literacy scale, International Journal of Research in Commerce and Management, vol. 4. , no. 1., 99.-104. pp.

18. Zsótér, B. - Nagy, P. (2012): Mindennapi érzelmeink és pénzügyeink Pénzügyi Szemle, vol. 57, no. 3., 310. - 321. pp. (Hungarian) 


\title{
ZAŠTO JE POTREBNO UČITI O FINANCIJAMA? REZULTATI NA TEMELJU MIŠLJENJA GENERACIJE $Z^{*}$
}

\author{
Ágnes Csiszárik-Kocsir ${ }^{4}$ \& Mónika Garai-Fodor ${ }^{5}$
}

\begin{abstract}
Sažetak
Koncepti financijske kulture i financijske pismenosti danas su popularne teme istraživanja. Brojna istraživanja i analize bave se temom financijske kulture stanovništva i pitanjem je li se ta kultura poboljšala deset godina nakon krize. Razlikuju se i istražuju različite dimenzije financijske kulture za različite dobne skupine stanovništva. Danas su sve države poduzele korake kako bi razvile i proširile financijsku pismenost, ali su ti koraci većinom zakašnjeli. Mnoge organizacije bave se mjerenjem financijske kulture na nacionalnoj i međunarodnoj razini. Rezultati istraživanja već su u mnogim slučajevima ukazali na nedostatke i na područja koja treba dalje razvijati, što je potrebno i važno.

Primarni akteri razvoja su obrazovne institucije na primarnoj, sekundarnoj i tercijarnoj razini. Međutim, znaju li studenti svrhu razvijanja financijske pismenosti, prepoznaju li njezinu važnost? Cilj rada je istražiti stavove studenata koji započinju visokoškolsko obrazovanje o financijskoj kulturi, financijskoj pismenosti, motivaciji i ciljevima kako bi se buduće generacije moglo pripremiti za izazove i očekivanja u financijama u budućnosti.
\end{abstract}

Ključne riječi: financijska kultura, financijska pismenost, generacija Z, visoko obrazovanje.

JEL klasifikacija: F65, I22

Rad je prezentiran na 3. Međunarodnoj konferenciji „Business \& Entrepreneurial Economics -BEE2018” koja je održana u Šibeniku od 30. svibnja do 2. juna 2018 (www.bee-conference.com)

4 Dr. sc. Ágnes Csiszárik-Kocsir, izvanredni profesor, Fakultet ekonomije i menadžmenta Keleti, Sveučilišste Óbuda, Budimšešta, Mađarska, E-mail: kocsir.agnes@kgk.uni-obuda.hu

5 Dr. sc. Mónika Garai-Fodor, docent, Fakultet ekonomije i menadžmenta Keleti, Sveučilište Óbuda, Budimpešta, Mađarska, E-mail: fodor.monika@kgk.uni-obuda.hu 